\title{
1. More effective private enforcement of EU law post-Lisbon: aligning regulatory goals and constitutional values
}

\section{Sara Drake*}

\section{INTRODUCTION}

Enforcement of European Union (EU) law through litigation by private parties before national courts ${ }^{1}$ plays a critical role in securing the effective compliance of EU law. This so-called private enforcement complements the public enforcement mechanism set out in Article 258 TFEU. $^{2}$ Together, they constitute the 'dual enforcement' system upon which the judicial enforcement of EU law has been traditionally based. This chapter evaluates the effectiveness of the EU's system of private judicial enforcement which has been developed predominantly by the Court of Justice of the European Union (CJEU) through its case law $^{3}$ by a process of adjudication. ${ }^{4}$ The case law centres around two overlapping and inter-

* I am grateful to Melanie Smith for comments on an earlier version of this chapter and to Stephanie Theophanidou for her research assistance. The usual disclaimer applies.

1 This is distinct from the rules governing the ability of private parties to judicially review EU law directly before the Union Courts by virtue of Article 263 TFEU. This provision was originally set out in the European Economic Community (EEC) Treaty, but revised by the Treaty of Lisbon to improve 'access to justice'.

2 The centralized public enforcement mechanism set out in Article 258 TFEU is discussed in $\mathrm{Ch} 2$ of this volume.

3 For a comprehensive account of the Court's case law, see Angela Ward, Judicial Review of and the Rights of Private Parties in EU Law (2nd edition, OUP, 2007).

4 Francis Snyder, 'The Effectiveness of European Community Law: Institutions, Processes, Tools and Techniques' in Terence Daintith (ed), Implementing EC Law in the United Kingdom: Structures for Indirect Rule (Wiley, 1995) at pp 51-87. 
linked stages of the litigation process. First, whether and how individuals can enforce rights conferred on them by EU law directly before their national courts. Second, as a corollary, and in the absence of EU harmonizing measures, which procedural rules apply and what legal remedies are available. The legal framework is complex, opaque and has been based (controversially) on a range of legal bases. The Court's policy has fluctuated in scope stemming from the complex interplay of competing zones of competence in the absence of a clear legal base in the Treaties, the different interests of the various actors, and friction between the kaleidoscope of constitutional values and regulatory goals which it seeks to pursue. The Treaty of Lisbon would have been an ideal opportunity to address the socalled 'enforcement deficit' 5 and to explicitly place the judge-made system of judicial enforcement on a sound, legal basis within the Treaty framework. Regrettably, this did not materialize. It follows that post-Lisbon the private enforcement system created by the Court is here to stay. That said, there are changes afoot, both constitutional and regulatory, which can improve the effectiveness of private enforcement in this post-Lisbon era and which need to be assessed.

The legal literature contains extensive accounts of the Court's jurisprudence which focus on the effectiveness of the key legal doctrines from the perspective of the individual litigant. In other words, to what extent can EU rights be enforced before national courts by private litigants? ${ }^{6}$ More interdisciplinary accounts explore the contribution of the doctrines to the constitutionalization process as well as the role of the Court and its relationship with national courts. ${ }^{7}$ Few scholars have yet to assess the private enforcement system in a holistic and systematic manner. This chapter will adopt an innovative, interdisciplinary approach to an assessment of the effectiveness of the private enforcement regime by drawing on regulatory scholarship. Based on the premise that the Court has constructed a regulatory scheme with effective compliance of EU law as its overarching goal, it will draw on the regulatory scholarship of Yeung ${ }^{8}$ and map the key principles and institutional design of the EU's private enforcement system against selected regulatory goals and constitutional values.

5 For a comprehensive analysis of the 'enforcement deficit', see Michael Dougan, National Remedies before the Court of Justice: Issues of Harmonisation and Differentiation (Hart, 2004).

6 See Ward, $n 3$.

7 Alec Stone Sweet, The Judicial Construction of Europe (OUP, 2004).

8 Karen Yeung, Securing Compliance: A Principled Approach (Hart, 2004). Yeung uses this framework in a similar way but in a different context, namely the public enforcement of competition law in Australia. 
This chapter's contribution to the literature is threefold. First, the chapter will go beyond traditional doctrinal accounts by analysing afresh the effectiveness of the private enforcement model from a broader, more contextual perspective. ${ }^{9}$ Second, within this analysis, the chapter will consider the impact of two legal innovations in the Treaty of Lisbon: the new Article 19(1), second subparagraph Treaty on European Union (hereinafter Article 19(1) TEU) which states that 'Member States shall provide remedies sufficient to ensure effective legal protection in the fields covered by Union law', and Article 47 of the now legally binding Charter of Fundamental Rights which explicitly refers to the right to an effective remedy. Third, by mapping the regulatory goals and constitutional values against the legal principles around which the regime is structured as well as its institutional features, it is possible to expose the inadequacies of the private enforcement system which jeopardize its effectiveness in a more systematic and objective manner. More importantly, it is argued that where the regulatory goals and constitutional values are most aligned, the system is operating most effectively.

This chapter will first set out the normative framework of analysis drawn from the regulatory scholarship and identify the regulatory goals and constitutional values chosen for the analysis (Section 1). This framework of analysis will be applied to the key foundational legal doctrines upon which the system is based, namely direct effect and indirect effect, and procedural rules and remedies including state liability (Section 2) as well as the new post-Lisbon innovations, namely Article 19(1) TEU and Article 47 of the Charter of Fundamental Rights (Section 3). The final section will go beyond the legal doctrines and map the framework against key institutional features of the private enforcement system (Section 4). The chapter will conclude by identifying the EU acquis where the regulatory goals and constitutional values work in harmony. This allows us to present a normative legal framework which promotes the private enforcement of EU law most effectively and pave the way for future research and policy development.

9 For an earlier attempt, see Snyder, n 4. 


\section{THE EFFECTIVENESS OF THE PRIVATE ENFORCEMENT OF EU LAW: A NEW FRAMEWORK OF ANALYSIS}

It is argued by regulatory scholars like Yeung ${ }^{10}$ that enforcement through litigation brought by private actors can be an effective policy choice for a number of reasons, particularly where the regulatory framework is designed to incentivize damages actions. Claims for damages actions can be instrumentally valuable as a deterrent and allow private actions to be aligned with public objectives. ${ }^{11}$ Damages actions can also be intrinsically valuable by providing compensation for those who have suffered loss resulting from a breach of the law and by (financially) punishing the infringer. Private actions can also play an important role in engaging citizens with the public interest goals served by regulation. As part of this regulatory strategy, the enforcement role of the Member State and/or EU is to provide the judicial framework for it to operate successfully and effectively, namely the court structure and procedural rules which govern legal proceedings. ${ }^{12}$

For the purpose of this chapter, Yeung's original framework has been transposed (with alterations) to a supranational context and to a private, decentralized system of enforcement created by a supranational court through its jurisprudence. The regulatory goals and constitutional values chosen represent the fundamental characteristics that a system of enforcement of EU rights should embody in a Union based on the rule of law whether public or private. They reflect the sui generis nature of the Union legal order, particularly the distinct role of the Court and the decentralized nature of private enforcement. The constitutional values do not replicate the values of the EU set out in Article 2 TEU in full, but some of these are included. Adherence to them need not be absolute (except for the constitutional value of legality ${ }^{13}$ ), but a question of degree. ${ }^{14}$ Using this framework is advantageous as it allows us to move forward the debate on effectiveness

10 See Karen Yeung, 'Privatising Competition Regulation' (1998) 18 OJLS 581-615. Whilst these arguments have been made in the context of the private enforcement of competition law at national level, they apply equally to the advantages of private enforcement in the EU across the full breadth of policy areas.

11 See further $\mathrm{Ch} 9$ in this volume.

12 Bronwen Morgan and Karen Yeung, An Introduction to Law and Regulation: Text and Materials (CUP, 2007) at $\mathrm{p} 216$.

13 Since this is identified by Yeung as a legal doctrine resting on respect for the rule of law and democratic governance, n 8 at $\mathrm{p} 45$.

14 Yeung refers to this as 'thin legality', n 8 at p 44. 
of the EU's private model by bringing together an assessment of the foundational legal (doctrinal) concepts set out by the Court in relation to the law on rights, remedies and procedural rules, in combination with the institutional design of this regulatory scheme operating in its social and political context. Viewing these aspects of the private enforcement system together reveals a more complete picture of its effectiveness, and identifies when it operates most effectively. It also allows new innovations, both constitutional and regulatory, to be assessed and to illuminate pathways for future research and policy development.

\subsection{Regulatory Goals}

The EU's private enforcement system is categorized as a regulatory scheme and the single, overarching collective goal of this regulatory scheme (as distinct from the substantive EU law that may need to be enforced) is deemed to be the effective compliance of EU law. It is argued that in Van Gend en Loos, the Court set out this paradigm when it stated that, 'The vigilance of the individuals concerned to protect their rights amounts to an effective supervision in addition to the supervision entrusted by Articles [258] and [259] to the diligence of the Commission and of the Member States. ${ }^{35}$

In order to achieve the overall regulatory goal, there are a number of more specific regulatory goals which taken together present the essential characteristics which a regulatory scheme of private enforcement should possess. The first ${ }^{16}$ regulatory goal is that of clarity and visibility. In the context of the EU's private enforcement model, this refers to the clarity of the legal rules espoused by the Court and the extent to which their content and application is understood by national courts, Member States, EU institutions, and individuals. Regulatory scholars consider that the most effective frameworks of regulation are those comprised of precise rules which are stable, consistently applied, not frequently altered, visible by those for whom they have been devised and not unduly complex or opaque. ${ }^{17}$ The second regulatory goal is that of predictability. This is an important goal of a legal framework because

\footnotetext{
15 Case 26/62 Van Gend en Loos [1963] ECR 1 at p 13. Emphasis added.

16 Yeung's first regulatory goal is that of efficiency, which requires an assessment of the desired outcome of the regulatory scheme with the lowest cost. This is outside the scope of this chapter. Suffice to say that such arguments have been raised in the context of private enforcement of competition law.

17 Yeung, $n 8$ at $\mathrm{p} 33$ citing Joseph Raz, 'The Rule of Law and its Virtue' (1977) 93 LQR 195 and CS Diver 'The Optimal Precision of Administrative Rules' in Robert Baldwin, Colin Scott and Christopher Hood (eds), A Reader on Regulation (OUP, 1998).
} 
it allows actors to act in a rational way in their self-interest. ${ }^{18}$ The third regulatory goal is that of flexibility. This goal may seem to conflict with those of clarity and predictability, but it has been argued by Yeung that flexibility is also required in a regulatory system in order to facilitate effectiveness. ${ }^{19}$ This goal concerns both the nature and content of the rules and in how they are interpreted and applied. A too formal adherence to legal rules can undermine their ability to achieve their objective. Flexibility on the other hand can facilitate their effectiveness since it can allow a more purposive approach to be applied to the interpretation and application of rules 'in order to give effect to their underlying purpose or "spirit." ${ }^{20}$ Such a teleological approach is a distinct feature of the CJEU's approach to its interpretation of EU law. Yeung also argues that regulatory schemes should aim to be responsive in the sense of being able to adapt and adjust within the environment in which they are operating. Hence, responsiveness is the final regulatory goal to be applied. ${ }^{21}$ If a scheme is unable to adapt, it can become ineffective and fail to fulfil its collective goal(s). ${ }^{22}$ This regulatory goal is particularly important in the regulatory context of the EU, which is dynamic and multi-level in nature, and in which changes to a regulatory regime at a transnational level can take a long time to agree and implement.

\subsection{Constitutional Values}

The constitutional values chosen act as constraints on the pursuit of the collective goal by the EU and its institutions. The first constitutional value to be applied is the need for the system to be authorized by law (legality). This requirement stems from adherence to the rule of law ${ }^{23}$ which in turn implies compliance with democratic legitimacy. ${ }^{24}$ In the context of the EU, Article 2 TEU now explicitly states that the Union is founded on the rule of law. ${ }^{25}$ The second value, which is closely connected to the first, is legiti-

18 Ibid, citing Max Weber's work and his analysis of law and social action in Law in Economy and Society (Harvard University Press, 1954).

19 Ibid at $\mathrm{p} 34$.

20 Ibid.

21 This is distinct from the theory of responsive regulation developed by Ayres and Braithwaite discussed in $\mathrm{Ch} 3$.

22 Ibid at $\mathrm{p} 35$.

23 Ibid at p 37 citing Raz, n 17. See also Paul Craig, 'Formal and Substantive Conceptions of the Rule of Law: An Analytical Framework' (1997) PL 467.

24 Ibid at p 37 citing Giandomenico Majone Regulating Europe (Routledge, 1996) 291-3.

25 It was the Court which first held in its Les Verts judgment that the now Union is based on the rule of law: Case 294/83 [1986] ECR 1339 at para 23. The 
macy. ${ }^{26}$ In this analysis, the focus will be on judicial legitimacy given the fundamental role played by the Court in the development of the private enforcement system through its case law. It refers to the Court's respect of the limits of its interpretative duties and powers in fulfilling its role set out in Article 19(1) TEU. ${ }^{27}$ The third constitutional value is that of certainty and stability. This requirement also stems from the rule of law and requires the law to be clear and certain in advance for those who will be subject to it, and not change too frequently. ${ }^{28}$ This is deemed to be particularly important where civil and criminal sanctions are imposed. ${ }^{29}$ The fourth constitutional value is the fair administration of justice. ${ }^{30}$ In the context of private enforcement, this represents a cluster of fundamental values based on fairness which must govern the judicial proceedings. In building the EU's private enforcement system, the Court has paid particular attention to determining the values it should protect and translating these values into legal rules upon which private litigants can depend. The principle of effective judicial protection has played a significant role and underpins many of the Court's judgments in which it has introduced rights for individuals such as the right of access to a court and the right to an effective remedy. The final constitutional value chosen is that of equality ${ }^{31}$ which requires substantive fairness, and which has particular significance in the EU context with rights conferred on individuals which may need to be enforced in the event of a breach in 28 Member States.

\subsection{Relationship between Regulatory Goals and Constitutional Values}

Yeung claims that it is possible for the regulatory goals and constitutional values to 'co-exist in harmony' as set out in Figure 1.1. ${ }^{32}$ However, there is undoubtedly scope for conflict, both between the different regulatory goals or constitutional values, as well as between the regulatory goals and constitutional values. How should such conflict be resolved? Yeung's theoretical framework provides a useful method for dealing with such

rule of law was inserted into the Treaty on European Union by the Treaty of Maastricht.

26 Note that this replaces Yeung's third constitutional value of accountability and transparency.

27 Formerly, in substance, Article 220 European Community (EC) Treaty.

28 Yeung, $\mathrm{n} 8$ at $\mathrm{p} 38$.

29 Ibid.

30 This is inspired by but broader than Yeung's fourth constitutional value of procedural fairness or due process.

31 For the purpose of this analysis, uniformity is incorporated within equality.

32 Yeung, n 8 at $\mathrm{p} 49$. 


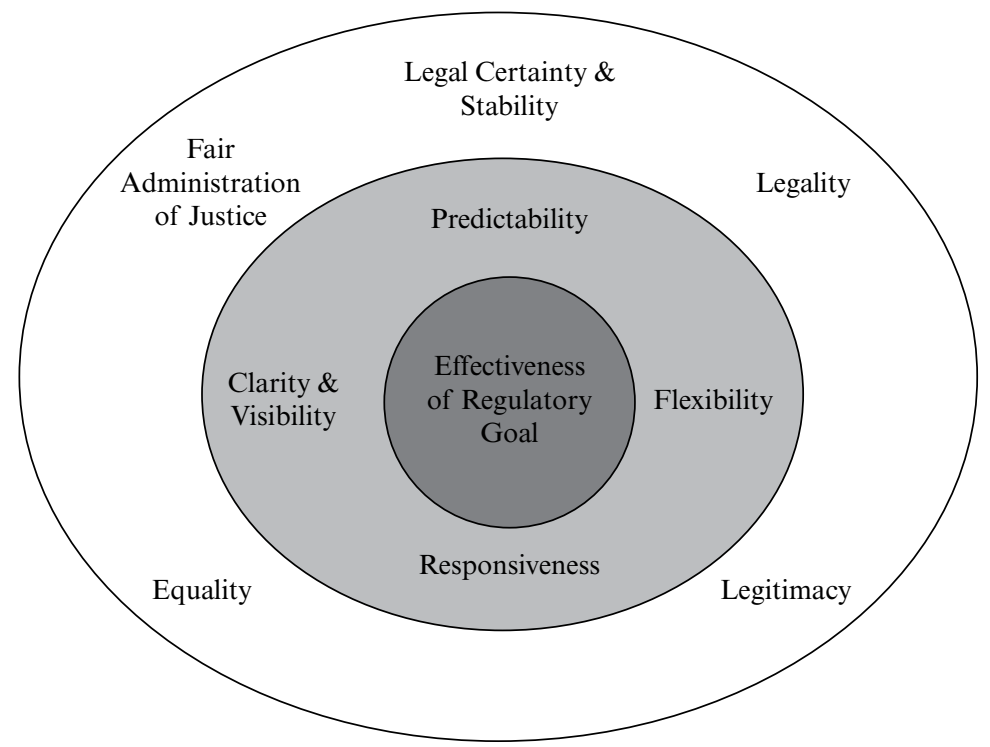

Figure 1.1 Regulatory goals and constitutional values

conflicts. First, where there is a conflict between regulatory goals the conflict should be resolved according to the particular context as well as to the overarching collective goal. Preference should be given to the goal which leads to long term substantive compliance. If any policy trade-offs are made these should be clearly explained (in this context by the CJEU). ${ }^{33}$ Second, where there is a conflict between constitutional values the conflict should be resolved in favour of the constitutional value which is most important (this may depend on the context). ${ }^{34}$ Third, where there is a conflict between constitutional values, the value which reflects a fundamental right should prevail. ${ }^{35}$ Fourth, should there be a clash between two fundamental rights, it may be a question of degree as to which one takes priority. ${ }^{36}$ Fifth, should a conflict arise between regulatory goals and constitutional values, Yeung argues against prioritizing the regulatory goals over constitutional values simply to achieve the overarching collective goal. In a liberal democratic society, regulatory goals may be promoted by public powers on condition that the constitutional values are also

33 Ibid at $\mathrm{p} 36$.

34 Ibid at $\mathrm{p} 45$.

35 Ibid at $\mathrm{p} 49$.

36 Ibid. 
respected. Adherence to these values to the requisite degree ensures that the pursuit of the regulatory goals by society is legitimate. ${ }^{37}$ Should the constitutional value provide the foundation for rights, once again the level of protection is one of degree; the regulatory goal(s) may be promoted on the ground that the fundamental core of the right is maintained. ${ }^{38}$

\section{THE EFFECTIVENESS OF THE LEGAL FRAMEWORK FOR PRIVATE ENFORCEMENT OF EU LAW}

The normative framework will be applied only to the foundational parts of the Union acquis which provides us with the key constructs of the Union's private system of enforcement: the doctrines of direct effect and indirect effect, the principles governing the application of procedural rules and remedies including the doctrine of state liability, and the initial principles constructed by the Court to ensure that its system of private enforcement complies with fundamental rights.

\subsection{Effective Enforcement and the Doctrine of Direct Effect}

The doctrine of direct effect is the foundational tenet upon which the system of private enforcement is based since it provides individual litigants with the ability to bring legal proceedings to protect their EU rights directly before a national court in the event of a breach. There is no doubt that direct effect plays an important role in achieving the overall collective regulatory goal of effective compliance of EU law as well as the effectiveness or effet utile of substantive provisions. Nevertheless, it is a view commonly held that the full potential of the doctrine to promote effective compliance with EU law is undermined by the Court's long-standing position that directives cannot have direct effect in horizontal situations. ${ }^{39}$ This can and does have a dramatic effect on the ability of some individuals to effectively enforce their EU rights and creates inequality between different private litigants. The classic example is the inability of an employee working in the private sector to enforce their directly effective rights against their employer, compared to an employee working in the public

\footnotetext{
37 Ibid at $\mathrm{p} 50$.

38 Ibid at $\mathrm{p} 50$.

39 In other words, directly effective provisions can only be enforced in actions between an individual and the state or an emanation of the state (vertical direct effect) and not in an action between two private parties (horizontal direct effect).
} 
sector who would be able to so. Paradoxically, in policy areas designed to protect individuals such as employment policy and consumer protection, the enactment of EU rights tends to be in the form of directives, rather than regulations. This long-held stance has been qualified somewhat by the Court's (controversial) 2005 ruling in Mangold, in which a Directive which gave expression to a specific general principle of EU law, namely the principle of non-discrimination on grounds of age, could be relied upon in an action between private parties. ${ }^{40}$

The Court's initial refusal to grant directives horizontal direct effect was arguably in response to criticisms of the Court's introduction of direct effect by adopting a teleological interpretation of the Treaty and basing it only minimally on the text of the Treaty. This raised questions about the legality and legitimacy of the Court's rulings by the Member States and their national courts, ${ }^{41}$ particularly in view of the role of direct effect in constitutionalizing the Treaties, as well as issues of legal certainty. Deeply aware that first and foremost the overall success of the private enforcement system relies on the acceptance of its ruling by the Member States and their national courts rather than adherence to those values which confer greater protection on the individual litigant, the Court responded by prioritizing legality, legitimacy and legal certainty over effective judicial protection and equality. Notwithstanding its ruling in Mangold ${ }^{42}$ the Court has maintained its prohibition on the horizontal direct effect of directives in later cases. From a regulatory perspective, the constraints placed on the development of the doctrine of direct effect

40 C-144/04 Mangold [2005] ECR I-9981. The Court's approach was confirmed and clarified post-Lisbon in C-555/07 Kücükdeveci [2010] ECR I-365 which also referred to the principle of age discrimination as set out in Article 21(1) of the Charter. The Mangold judgment attracted a great deal of criticism from both judicial and political quarters and was subject to a constitutional review by the German Federal Constitutional Court: Honeywell Re, BVerfG, 2 BvR 2661/06 [2011] 1 CMLR 33. In light of this, it is unsurprising that its reach has been curtailed in subsequent case law: see in particular, C-282/10 Dominguez [2012] EU:C:2012:33 which concerned the right to paid annual leave, which also appears in Article 31(2) of the Charter. See further, Mirjam de Mol, 'Dominguez: A Deafening Silence (Case Comment)' (2012) 8(2) European Constitutional Law Review 280-303.

41 The French and German courts refused to recognize the direct effect of directives: Ministre de l'Intèrieur v Daniel Cohn-Bendit [1980] 1 CMLR 543; Re Value Added Tax Directives (Case V B 51/80) [1982] 1 CMLR 527.

42 It is noteworthy that the Court has been required to retreat from applying its Mangold decision more broadly for similar reasons. Whilst the judgment clearly prioritizes the constitutional values of equality and effective judicial protection, it undermines legal certainty as well as the legitimacy and legality of the Court's jurisprudence. 
by the differing constitutional values have led to a lack of visibility, clarity and predictability. Yet, this seems to be of a degree currently acceptable.

It is suggested that codification of the doctrine in the Treaty framework would be a clear way of improving the effectiveness of direct effect as a means of achieving effective compliance of EU law and allow for greater alignment of the regulatory goals and constitutional values. However, this would be difficult given the uncertainty amongst legal scholars in the different Member States as to its exact meaning ${ }^{43}$ as well as previous hostility shown by the Member States to the doctrine. ${ }^{44}$ The time may come for the EU institutions and the Member States to show a greater commitment to the private enforcement regime and agree to explicitly state whether a provision has direct effect when it is being enacted and recognize the horizontal direct effect of directives.

\subsection{Effective Enforcement and the Doctrine of Indirect Effect}

The scope of the doctrine of direct effect as a means of ensuring effective compliance of EU law has been limited as a result of the Court's strict adherence to its interpretation of legality and the rule of law, trumping the constitutional values of effective judicial protection and equality based on fairness. Nevertheless, the Court has acted responsively and flexibly in developing alternative legal avenues for individuals to enforce their EU rights before national courts. ${ }^{45}$ The most significant and now wellentrenched doctrine developed by the Court is that of 'indirect effect', also referred to as the principle of consistent interpretation. ${ }^{46}$ In Von Colson ${ }^{47}$ the Court held that a national court is under a duty to interpret national law to comply with EU law. This allows individuals to secure their EU rights indirectly by virtue of national law, and independently of direct effect. Indeed, an empirical study, dating back to 1998, demonstrated

43 Paul Craig and Gráinne de Búrca, EU Law: Text, Cases and Materials (3rd edition, OUP, 2003) pp 178-82.

44 Article 34 TEU (M) expressly states that framework decisions, similar instruments to directives, do not have direct effect. This provision was repealed by the Treaty of Lisbon 2009.

45 Unfortunately, there is insufficient space to map the framework onto the principles emanating from the Court's judgments in Case C-194/94 CIA [1996] ECR I-2201 ('incidental' horizontal direct effect).

46 See further Sara Drake, 'Twenty Years after "Von Colson": The Impact of "Indirect Effect" on the Protection of the Individual's Community Rights' (2005) 30 ELRev 329.

47 Case 14/83 Von Colson [1984] ECR 1891. 
that whilst in theory the principle of direct effect is regarded as the starting point for an individual seeking to enforce their EU rights because it guarantees full compliance with a right, in practice, it is the principle of indirect effect that is the main legal mechanism for enforcing EU rights before British courts. ${ }^{48}$ The doctrine has been further strengthened in subsequent case law. ${ }^{49}$

The principle of indirect effect addresses the inequality in the enforcement of rights depending on the status of the defendant and secures the constitutional value of effective judicial protection to a large degree. However, once again, tensions arise as to the doctrine's compliance with legality. This teleological interpretative approach of the Court has created tension regarding the legitimacy of its rulings. The doctrine can also create legal uncertainty for both the claimant and the defendant since the outcome is dependent on the interpretation of the national judge. In terms of regulatory goals, this can affect clarity and predictability. In subsequent case law, the Court sought to enhance the legality and legitimacy of the doctrine by ruling that the duty imposed on national courts is 'inherent in the system of the [TFEU]'. ${ }^{50}$ The Court has acted responsively and flexibly in developing this doctrine in order to secure effective compliance with EU law and has prioritized the constitutional values of effective judicial protection and equality over strict compliance with legality, legitimacy and legal certainty.

\subsection{Effective Enforcement and Procedural Rules and Remedies}

One of the most contentious areas in the construction of the EU's private enforcement system has been the determination of the procedural and remedial laws that should apply. ${ }^{51}$ In the absence of EU secondary legislation regulating such matters, the Court's approach veers somewhere between the two different approaches set out below. First, its default position has been to respect the national procedural and remedial autonomy of the Member States subject to EU minimum standards. This means that national procedural rules and remedies apply provided they do not treat actions based on EU law less favourably than similar actions based on domestic law (principle of equivalence) and the national rules must not make it practically impossible or excessively difficult to bring a claim

\footnotetext{
48 Damian Chalmers, 'The Positioning of EU Judicial Politics within the United Kingdom' (2000) 23 WEP 169, 190.

49 Joined Cases C-397-403/01 Pfeiffer [2004] ECR I-8835.

50 Ibid.

51 For a comprehensive account of this area of EU law, see Dougan, n 5.
} 
based in EU law (principle of effectiveness ${ }^{52}$ ). The national court makes this assessment:

by reference to the role of that provision in the procedure, its progress and its special features, viewed as a whole, before the various national instances. In light of that analysis the basic principles of the domestic judicial system, such as the protection of rights of the defence, the principle of legal certainty and the proper conduct of proceedings must, where appropriate, be taken into consideration. ${ }^{53}$

This initial approach of the Court is based on the principle of loyal or sincere co-operation set out in Article 4(3) TEU which applies to all institutions of the Member States including the judiciary. By taking national procedural autonomy as its starting point, the legitimacy of this approach has not been challenged by the Member States or their courts. The formula allows national courts some discretion provided that the overall goal of effective enforcement of EU law is not jeopardized. In this sense, the principles of equivalence and effectiveness play an important role in delineating the zones of competence between the EU and Member State which could be argued to be in compliance with the principle of subsidiarity and proportionality. Under this first approach, the constitutional values and regulatory goals work in harmony to a large degree. The principles of effectiveness and equivalence are in themselves clear and predictable and given the level of discretion granted to the national courts can be applied in a responsive and flexible manner. The main downside of this approach is that it can cause inequality between individual litigants across the Member States who will be subject to different rules which can affect their ability to effectively enforce their EU rights. This can cause a degree of legal uncertainty for litigants and may obscure an individual's ability to assess the likely success of a claim.

A second, more interventionist approach emerged in the mid-1980s based on a teleological interpretation of the law. The Court's request for EU secondary legislation to be enacted on a general scale was not forthcoming. ${ }^{54}$ The jurisprudence from this period has given rise to an important body of legal principles setting out uniform remedies ${ }^{55}$ and

\footnotetext{
52 Note the multiple uses of the term 'effectiveness' with different meanings in this area of EU law.

53 Cases C-430-431/93 Van Schijndel [1995] ECR I-4705 at para 19. See also Case C-312/93 Peterbroeck [1995] ECR I-4599.

54 See, for example, Case 130/79 Express Dairy Foods [1980] ECR 1887 para 12.

55 This includes the right to repayment of unlawful levies and the right to interim relief: Case 199/82 San Giorgio [1983] ECR 3595; Case C-213/89 Factortame (No 1) [1990] ECR I-2433.
} 
common procedural rules derived from EU law rather than national law. This phase of the Court's case law culminated in the Court's Francovich ${ }^{56}$ decision in which it introduced the EU remedy of state liability, which grants individuals an EU right to bring an action for damages against a Member State.

The main advantage of this second approach is that it promotes the effective enforcement of EU law by granting private litigants greater legal certainty, equality and effective judicial protection through uniform remedies derived from EU law. This removes the vagaries of the national legal systems and promotes clarity and predictability. There is also scope for flexibility and responsiveness in that whilst the existence of the remedy is derived from EU law, it is exercised in accordance with national rules subject to the principles of effectiveness and equivalence.

The Court's Francovich ruling represents the zenith of its expansionist case law in creating a private system of enforcement in pursuit of the collective goal of effective enforcement of EU law. By examining state liability through the two normative lenses, it can be seen that the constitutional values and regulatory goals are in harmony, achieving high levels of effective judicial protection for individual actors, and yet maintaining some scope for flexibility and responsiveness. Notwithstanding these benefits, the Francovich ruling is well known amongst legal scholars and political scientists for the controversy it raised in terms of legitimacy. It provoked strong political reactions from the Member States $^{57}$ which accused the Court of having insufficient legal authority to create this new remedy. ${ }^{58}$

In response to the challenges to the legitimacy of its rulings which follow this second approach, the Court is considered to have embarked on a limited retreat, entering a period which has been termed 'selective deference ${ }^{59}$ or 'judicial restraint' ${ }^{60}$ In other words, the Court's standard approach now is to allow national rules to be applied subject to the

\footnotetext{
56 Joined Cases C-6/90 and 9/90 Francovich [1991] ECR I-5357.

57 At the IGC 1996, the UK proposed inter alia that the Francovich and Case C-208/90 Emmott v Minister for Social Welfare [1991] ECR I-4269 rulings be curbed: Jonas Tallberg 'Supranational Influence in EU Enforcement: The ECJ and the Principle of State Liability' (2000) 7 Journal of European Public Policy 104.

58 Empirical research suggests that the remedy has had limited success: Tobias Lock 'Is Private Enforcement of EU Law through State Liability a Myth? An Assessment 20 Years after Francovich' (2012) CMLR 1675.

59 Takis Tridimas, 'Enforcing Community Rights in National Courts: Some Recent Developments' in Claire Kilpatrick, Tonia Novitz and Paul Skidmore, The Future of Remedies in Europe (Hart Publishing, 2000) 35 at p 49.

60 Anthony Arnull, 'The Principle of Effective Judicial Protection in EU Law: An Unruly Horse?' (2011) 36 ELR 51-70.
} 
principles of effectiveness and equivalence, and only occasionally intruding on the national procedural autonomy of the Member States to develop or refine its existing framework of EU remedies. ${ }^{61}$ The main problem with this current approach in terms of meeting its regulatory goals is its lack of clarity and predictability and the corresponding constitutional value of legal certainty. In any given case, it is not clear which approach the Court will adopt. The application of our two normative lenses reveals that the current approach of 'selective deference' seems to be the least appropriate in order to achieve effectiveness.

\subsection{Effective Enforcement and Fundamental Rights}

The EU's system of private enforcement is bolstered by a strand of sometimes overlapping case law which sets out the fundamental right to an effective remedy, including the right of access to a court. ${ }^{62}$ This would fall within our constitutional value of fair administration of justice. It is this aspect of the Court's jurisprudence on private enforcement in which the constitutional values and regulatory goals set in our normative framework are the most aligned. The legitimacy of this strand of the case law on private enforcement is far stronger given that the Court sought to derive its legality from the national constitutional traditions of the Member States and fundamental rights reflecting fair administration of justice set out in the European Convention of Human Rights (ECHR). ${ }^{63}$ More recently, the Court ruled in its Unibet judgment that the (broader) principle of effective judicial protection incorporating the right to an effective remedy including access to a court is a general principle of EU law. ${ }^{64}$ This provides legal certainty, greater equality, and common standards of fundamental rights in the Member States. This is an example of the constitutional values working in harmony. In terms of regulatory goals, the rules are for the most part clear and predictable. However, from a doctrinal perspective, there are deep concerns about the lack of clarity over the Court's use of

61 See, for example, Case C-224/01 Köbler [2003] ECR I-10239 and Case C-453/99 Courage [2001] ECR I-6297.

62 Case 222/84 Johnston [1986] ECR 1651; Case 222/87 Heylens [1987] ECR 4097; Case C-185/97 Coote [1998] I-5199.

63 Article 6 ECHR confers on everyone the right to a fair and public hearing before an independent and impartial tribunal established by law and within a reasonable time when determining civil rights and obligations or any criminal charge brought against them; Article 13 states that everyone whose rights and freedoms set out in the ECHR which have been violated has a right to an effective remedy before a national authority.

64 See Case C-432/05 Unibet [2007] ECR I-2271 at para 37. 
the terms 'effective judicial protection' and 'effective remedy' and how these relate to its extensive body of case law on remedies (discussed above) for their meanings vary in different contexts. It is important to recall that not all aspects of private enforcement raise issues of fundamental rights, but they can entail the protection of (lesser) constitutional values, for example, recovery of sums levied by Member States in breach of EU law and national time limits. ${ }^{65}$

\section{THE IMPACT OF POST-LISBON INNOVATIONS ON THE EFFECTIVENESS OF THE PRIVATE ENFORCEMENT MODEL}

The aim of the Treaty Establishing a Constitution for Europe 2004 (also known as the Constitutional Treaty) which morphed into the Treaty of Lisbon was to provide the framework for the functioning of the EU for the next 50 years. Yet, what is astonishing from a private enforcement perspective is that given its crucial role in the enforcement of EU law, there is a remarkable absence of discussion or proposals to increase its visibility and codify its key characteristics such as direct effect, ${ }^{66}$ state liability and the principles of effectiveness and equivalence. Moreover, there were no references to the key role played by the national courts in enforcing EU law. ${ }^{67}$ Nevertheless, the Treaty of Lisbon contains two new constitutional provisions which could play a significant role in improving the effectiveness of the private enforcement system, particularly remedies and procedural rules - Article 19(1) TEU and Article 47 of the Charter of Fundamental Rights. The application of these innovations by the Court will be explored in this section and analysed in light of our two strands of normative standards. The analysis reveals that post-Lisbon we have

65 See, for example, the case law in relation to national time limits in which the CJEU has tried to strike the balance between the sound administration of the national legal orders and legal certainty and the effective protection of individuals' directly effective EU rights: see discussion in Anthony Arnull, The European Union and its Court of Justice (2nd edition, OUP, 2006) at pp 300-304.

66 It could be argued that the attempt to insert the primacy provision into the Constitutional Treaty was an attempt to recognize its important role in the constitutionalization of the Treaty, but there is no equivalent attempt relating to its twin principle of direct effect. For discussion against incorporating direct effect into the Constitutional Treaty and the difficulties this would raise, see Monica Claes, The National Courts' Mandate in the European Constitution (Hart Publishing, 2006) at p 679.

67 Ibid at pp 680-83. 
moved into a new phase in the Court's case law on remedies and procedural rules before national courts which have important ramifications for the effectiveness of the private model of enforcement. However, the Court has not yet harnessed the full potential of these provisions to improve the effectiveness of the private model overall.

\subsection{Article 19(1) TEU: The Missing Legal Base or More?}

The new Article 19(1) TEU states that 'Member States shall provide remedies sufficient to ensure effective legal protection in the fields covered by Union law. ${ }^{68}$ It is clear from the discussions on the Court of Justice within the Convention on the Future of Europe which led to the signing of the Constitutional Treaty ${ }^{69}$ that this addition was introduced in order to complement the broadening of access for individuals under Article 263(4) TFEU and reinforce the Court's controversial claim in $U P A$ that the Treaties created a 'complete system of legal remedies and procedures designed to ensure judicial review of the legality of acts of the institutions, and has entrusted such review to the [Union] Courts', ${ }^{70}$ rather than to address the legality and legitimacy deficit of the Court's judge-made remedies system before national courts. This narrow view has been confirmed by the Court post-Lisbon in its Inuit judgment. ${ }^{71}$ This is in line with the principle of effective judicial protection which the national courts are under a duty to respect in accordance with Article 4(3) TEU. ${ }^{72}$ Nevertheless, it is clear that the provision is broad enough to cover not only judicial review actions and the fundamental right of access to effective judicial review before a national court, but all litigation where national courts are involved in the enforcement of Union law. ${ }^{73}$ Most importantly, it has the potential to provide the CJEU at the very least with a more legitimate legal basis for its existing system of remedies which would in turn grant the national courts a stronger mandate for engaging in their enforcement role.

\footnotetext{
68 This provision survived the Constitutional Treaty: Article I-29.

69 See the Discussion Circle on the Court of Justice: Final Report of 25 March 2003 at $\mathrm{p} 6$.

70 Case C-50/00P UPA [2002] ECR I-6677 at para 40. It should be noted that this is contrary to the views of a swathe of academic commentators and Advocates General, the most prominent critic being Advocate General Jacobs: see his Opinion in $U P A$.

71 Case C-583/11P Inuit EU:C:2013:625 at para 90.

72 Case C-50/00P at paras 41-2.

73 Claes, n 66 at p 683.
} 
A survey of the case law post-Lisbon illustrates that this is indeed the approach being adopted by some of the Advocates General, particularly in litigation involving the recovery of sums from the Member States that have been unlawfully levied. In Banca, Advocate General Mazák claims that Article 19(1) TEU imposes on Member States and their national courts the same obligations that have arisen pre-Lisbon under the principles of effectiveness and equivalence. ${ }^{74}$ Admittedly, hidden away in a footnote, in Macinský, Advocate General Wahl referred to Article 19(1) TEU as 'enshrining' aspects of the principle of effectiveness originally set out in Rewe and Comet. ${ }^{75}$ For some, Article 19(1) TEU provides an additional guarantee of effective remedies giving rise to its own obligations. For example, in Test Claimants (No. 3), Advocate General Wathelet argues that Article 19(1) TEU formalized the obligation on Member States to provide effective remedies that had already been set out in UPA (in the context of judicial review). ${ }^{76}$ He then goes on to apply it in the context of an action for recovery of sums unlawfully levied as a supplement to the principles of effectiveness and equivalence. ${ }^{77}$ In Donau Chemie, Advocate General Jääskinen goes further and argues that the standard of effective judicial protection that should be provided by national courts should be reconsidered in light of the new Article 19(1) TEU. He held that in light of this 'supplementary guarantee' found in the Treaty, '. . the standard of effective judicial protection for EU based rights seems to be more demanding than the classical formula referring to practical impossibility or excessive difficulty. In my opinion this means that national remedies must be accessible, prompt, and reasonably cost effective. ${ }^{78}$

The Court's approach to Article 19(1) TEU has been more tentative than that of some of the Advocates General. In many cases on remedies, there is no mention of the provision at all. The Court has referred to it several times in combination with Article 47 of the Charter of Fundamental Rights stating that its role is to ensure that Article 47

74 Opinion of Advocate General Mazák in Case C-427/10 Banca [2011] ECR I-13377 at para 16.

75 See Opinion of Advocate General Wahl in Case C-482/12 Macinský EU:C:2013:765 at footnote 26.

76 Opinion of Advocate General Wathelet in Case C-362/12 Test Claimants in the Franked Investment Income Group Litigation (No 3) EU:C:2013:834 at para 34.

$77 \mathrm{He}$ argued that in accordance with Article 19(1) TEU a remedy is not 'effective' if the conditions in which it can be invoked successfully are not known in advance. Ibid, at paras 46-7.

78 Opinion of Advocate General Jääskinen in Case C-536/11 Donau Chemie EU:C:2013:366 at para 47 and reiterated in Case C-61/14 Orizzonte Salute EU:C:2015:307 at footnote 23. 
is respected by the Member States. ${ }^{79}$ The Court has also referred to Article 19(1) TEU as an additional and more specific obligation to the principle of sincere co-operation set out in Article 4(3) TEU and the duty imposed on Member States to ensure judicial protection of an individual's rights under EU law. ${ }^{80}$ It is strongly argued that the effectiveness of the EU's private enforcement system would be improved if the Court explicitly based the principles of effectiveness and equivalence on Article 19(1) TEU. It would strengthen the legality and legitimacy of this key feature of its private system of enforcement and promote legal certainty. From a regulatory perspective, a clearer legal base would improve clarity and predictability, whilst there is sufficient discretion granted to Member States to maintain flexibility and responsiveness. Whether the qualitative standard of effective legal protection would be enhanced depends on whether the Court follows the approach suggested by Advocate General Jääskinen in Donau Chemie and uses Article 19(1) TEU as the basis of higher standards, but which intrude further on the national procedural autonomy of the Member States in a nonfundamental rights context.

\subsection{Article 47 of the Charter on Fundamental Rights: Moving Closer to Aligning Regulatory Goals and Constitutional Values}

The Treaty of Lisbon marks a new era in the protection of fundamental rights under EU law. Article 6(1) TEU finally grants the Charter of Fundamental Rights of the European Union (EUCFR) equal legal status with the Treaties. ${ }^{81}$ It is now legally binding on the EU institutions and Member States, but only 'when implementing EU law'82 and is subject

79 See, for example, Case C-418/11 Texdata EU:C:2013:588 at para 78; Case C-562/12 Liivimaa Lihaveis MTÜ EU:C:2014:2229 at para 68.

80 Case C-404/13 ClientEarth EU:C:2014:2382 at para 52 citing Case C-432/05 Unibet [2007] ECR I-2271 at para 38.

81 The Charter was 'solemnly proclaimed' in 2000: [2000] OJ C364/1. An adapted version became legally binding on 1 December 2009 along with the Treaty of Lisbon: [2012] OJ C326/02. During this interim period, the Charter still had influence on the Court's rulings: see further Sara Iglesias Sánchez, 'The Court and the Charter: The Impact of the Entry into Force of the Lisbon Treaty on the ECJ's Approach to Fundamental Rights' (2012) 49 CMLR 1565, 1569-73.

82 Article 51(1) EUCFR. It should be noted that the Court has adopted a very broad interpretation of this phrase in Case C-617/10 Fransson EU:C:2013:105 to the extent that it is difficult to consider an area of EU law which is not now subject to the Charter. 
to important limitations and exceptions. ${ }^{83}$ The importance of this development for the EU's private enforcement model lies in Article 47 of the Charter of Fundamental Rights which is found under Title VI entitled Justice and explicitly refers to the right to an effective remedy and to a fair trial. It states that:

Everyone whose rights and freedoms guaranteed by the law of the Union are violated has the right to an effective remedy before a tribunal in compliance with the conditions laid down in this Article.

Everyone is entitled to a fair trial and public hearing within a reasonable time by an independent and impartial tribunal previously established by law. Everyone shall have the possibility of being advised, defended and represented.

Legal aid shall be made available to those who lack sufficient resources in so far as such aid is necessary to ensure effective access to justice.

The Charter is accompanied by Explanations which act as an interpretative aid to its provisions. ${ }^{84}$ The Explanations confirm that Article 47 is based on Articles 6(1) and 13 of the ECHR and emphasize that the right to an effective remedy set out in Article 13 ECHR has already been established as a general principle of EU law by the CJEU, which was based in part on these provisions of the ECHR as well as the constitutional traditions of the Member States. ${ }^{85}$

The principal advantage for individual litigants is that they have been granted a new source of (primary) law to challenge the legality of EU law and national law which is 'implementing EU law' in relation to, inter alia, their right to an effective remedy. There is no question that individuals (and their lawyers) are seizing on the Charter as a 'sword' with a large number of preliminary rulings being made to the CJEU concerning the interpretation and scope of Article 47. Although the language of direct effect has

83 Articles 52-54 EUCFR set out limits to its scope and the interpretation of rights and principles. See also Protocol No. 30 on the application of the Charter of Fundamental Rights of the European Union to Poland and the United Kingdom. Note that in Joined Cases C-411/10 and C-493/10 N.S. [2011] ECR I-13905, a reference from the Court of Appeal of England and Wales, the CJEU held that Protocol 30 does not generally disapply the Charter in the UK.

84 See Article 52(7) EUCFR which requires the Union courts and the national courts to take the explanations into account when interpreting the Charter.

85 The Explanations also confirm that Article 47 is wider in scope than both Articles 6(1) and 13 of the ECHR. Unlike Article 13 ECHR, Article 47 refers to the right to an effective remedy before a court and not just before a national authority. Article 47 is also broader than Article 6(1) ECHR in that it is not restricted to disputes relating to civil law rights and obligations since the EU is a Community (now Union) based on the rule of law. 
not been used, ${ }^{86}$ individuals have successfully relied on Article 47 vertically to strike down conflicting EU and national legislation. ${ }^{87}$ In so doing, this litigation is forcing the Court to consider the contours of Article 47 and its relationship with its existing case law on remedies discussed above. Whilst a comprehensive exploration of the case law is outside the scope of this chapter, it is possible to discern a number of trends emerging in the Court's case law in which Article 47 EUCFR has been invoked. What will become clear is that this constitutional innovation is fast emerging as a new foundational pillar around which the law on procedural rules and remedies is starting to orbit. Undoubtedly, it has huge potential to improve the effectiveness of the EU's private enforcement system since it provides an opportunity for a more complete alignment of the regulatory goals and constitutional values. ${ }^{88}$

\section{Article $\mathbf{4 7}$ as a new source of fundamental rights}

One of the most interesting new trends to emerge is where the Charter has been drawn upon by the CJEU as the main source of EU law in accordance with which national courts should interpret national procedural law and remedies when implementing EU law. In its $D E B$ judgment, ${ }^{89}$ the Court seized the opportunity to reformulate the question referred by the German court from one concerning the principle of effectiveness and whether it was being infringed by the German provision to one relating to the interpretation of Article 47 and placing this provision centre stage. Admittedly, the Court may have been influenced by the fact that it was being given the opportunity for the first time to rule on the interpretation of EU law in relation to national provisions on legal aid contained in Article 47, third paragraph, where there is no existing EU case law on this issue. The Court drew quite significantly on the existing case law of the European Court of Human Rights (ECrtHR) on legal aid promoting an alignment of the different sources of fundamental rights law on

\footnotetext{
86 Paul Craig and Gráinne de Búrca, EU Law: Text, Cases and Materials (6th edition, OUP, 2015) p 196.

87 The CJEU has yet to declare that provisions of the Charter have horizontal direct effect. Nevertheless, in Benkharbouche v Sudan and Janah v Libya, the Court of Appeal (England and Wales) (Civil Division) held that since Article 47 EUCFR reflects a general principle of EU law and following the approach of the CJEU pre-Lisbon in Case C-144/04 Mangold [2005] ECR I-9981 and post-Lisbon in Case C-555/07 Kücükdeveci [2010] ECR I-365 and Case C-176/12 AMS EU:C:2014:2, it has horizontal direct effect: [2015] EWCA Civ 33 at paras 69-81.

88 This argument applies equally to the procedures which apply before the EU institutions, but this issue is outside the scope of this chapter.

89 Case C-279/09 DEB [2010] ECR I-13849.
} 
this issue. ${ }^{90}$ Thus, the $D E B$ judgment not only promotes more effective judicial protection for individuals asserting their EU rights grounded in fundamental rights, but also ensures greater clarity and predictability in the case law.

\section{Article 47 and the right to an effective remedy as a general principle of law}

Whilst such an approach on the part of the Court is unsurprising in relation to the new provisions of Article 47 on legal aid, the Court's approach has been more mixed in relation to the first paragraph of Article 47, which refers to the right to an effective remedy. In many of the post-Lisbon cases, the Court has ruled that Article 47 is simply an affirmation of the well-established right to an effective remedy. It is therefore recognized as a supplementary source of fundamental rights. ${ }^{91}$ It could be argued that this approach is understandable given the incremental and chronological development of fundamental rights protection in EU law as well as the limitations on the scope of the Charter's application. Yet, an interesting development has arisen in some later cases where the Court has referred to Article 47 first in its reasoning followed by the right to an effective remedy as a general principle of EU law. For example, in Liivimaa Lihaveis $M T \ddot{U},{ }^{92}$ the Court drew on Article 47 as its main source for its ruling, and its traditional case law as an additional source of fundamental rights.

Is there any significance that should be given to this subtle reordering of the different sources of fundamental rights protection? On the one hand in both types of cases, the Court's recognition of different sources denotes a pluralistic approach which is consistent with some views of the Charter ${ }^{93}$ and arguably implicit in Article 53 EUCFR. ${ }^{94}$ Yet, it could also be argued that in cases like Liivimaa Lihaveis MTÜ, by starting its reasoning with the Charter, the Court is placing it at the apex of the sources of fundamental rights protection and recognizing it as the pre-eminent source of fundamental rights in EU law. This would suggest that the Court is trying to create a more hierarchical, but coherent and consistent body of case law

\footnotetext{
90 This is in compliance with Article 52(3) EUCFR.

91 See Joined Cases C-317-320/08 Alassini [2010] ECR I-02213; Case C-93/12 ET Agrokonsulting EU:C:2013:432.

92 Case C-562/12 Liivimaa Lihaveis MTÜ EU:C:2014:2229.

93 See Advocate General Bot in Case C-399/11 Melloni EU:C:2013:107.

94 Article 53 EUCHR complements Articles 51 and 52 and states that '[n]othing in this Convention shall be construed as limiting or derogating from any of the human rights and fundamental freedoms which may be ensured under the laws of any High Contracting Party or under any other agreement to which it is a Party'.
} 
which complies with its own vision of the EU legal order ${ }^{95}$ and a system of remedies grounded in fundamental rights.

\section{Article 47 and the principles of effectiveness and equivalence}

This brings us on to the relationship between Article 47 and the principles of effectiveness and equivalence, which is far from clear and a number of different approaches are emerging. In $D E B$, the Court refused to adopt its classic approach and base its ruling on the principle of national procedural autonomy subject to the principles of effectiveness and equivalence, but used Article 47 as its main source of law together with the case law of the ECrtHR. In Alassini,${ }^{96}$ an earlier case concerning the implementation by Italy of elements of the Universal Services Directive dealing with consumer disputes, the CJEU first applied the principle of national procedural autonomy subject to the principles of equivalence and effectiveness as set out in its traditional case, and then secondly, and as a separate part of the adjudication, made an assessment on the basis of fundamental rights. It referred to 'the principle of effective judicial protection as a general principle of EU law stemming from the constitutional traditions common to the Member States, which has been enshrined in Articles 6 and 13 of the ECHR and which has also been reaffirmed by Article 47 of the Charter of Fundamental Rights'. ${ }^{97}$ Recalling both its own case law and that of the ECrtHR, the Court ruled that fundamental rights are not absolute and may be curtailed by restrictions which are in the general interest, proportionate and do not amount to an 'intolerable interference which infringes upon the very substance of the rights guaranteed'.$^{98}$ Thus, the Court adopted a pluralist approach and conducted its adjudication using two juridically distinct strands of case law. ${ }^{99}$ The dividing line is not always clear and can be difficult to draw. There have been calls by Advocates General Bot and Jääskinen to consider the principles of effectiveness and equivalence as falling under the umbrella of Article 47. ${ }^{100}$ Whilst this proposal sounds laudable, it

95 Advocate General Bot in C-399/11 Melloni, n 93 and Damian Chalmers, Gareth Davies and Giorgio Monti, European Union Law (3rd edition, CUP, 2014) pp 259-75.

96 Joined Cases C-317-320/08 Alassini, n 91 at paras 61-3.

97 Ibid para 61.

98 Ibid para 63.

99 For discussion of the separate nature of these two 'tests' to be conducted at court, see Advocate General Jääskinen in Case C-61/14 Orizzonte Salute EU:C:2015:307 at paras 33-7.

100 See Opinion of Advocate General Jääskinen in Case C-562/12 Liivimaa Lihaveis MTÜ EU:C:2014:2229 at para 47; Case C-61/14 Orizzonte Salute 
does require clarification about the interrelationship between the two strands of law.

In a third category of cases, the Court has referred to Article 47 in conjunction with the principles of effectiveness and equivalence. In Unitrading $L t d,{ }^{101}$ the Court ruled on the interpretation and scope of Article 47 with regard to the rights of the defence. In the absence of EU law governing further aspects of the national customs procedure at issue such as the concept of evidence, the Court applied the principles of effectiveness and equivalence. In this respect, it held that Article 47 had not been infringed provided that the national procedural law in question complied with the principles of effectiveness and equivalence. So whilst Article 47 and the principles of effectiveness and equivalence were applied separately in its adjudication by the Court, they are closely connected to the extent that the Court held that compliance with Article 47 requires the principles of effectiveness and equivalence to be satisfied when a Member State applies its own national procedural rules.

In a fourth category of cases, the Court has not mentioned the Charter at all. In Nicula, ${ }^{102}$ a Grand Chamber judgment concerning the repayment of unlawful taxes, the Court relied on its well-established case law. This is understandable given that repayment of unlawful taxes is not usually a fundamental rights issue. More broadly, it is argued that it illustrates that the Court is keen to maintain a distinction between the different strands of its remedies case law.

\section{Aligning regulatory goals and constitutional values}

Article 47 EUCFR presents a more visible and highly legitimate legal basis upon which the Court can develop its standards of fundamental rights protection in relation to the right to an effective remedy. A clear advantage to this approach is that Article 47 of the Charter grants national courts more confidence to strike down national law and impose EU standards. ${ }^{103}$ Article 47 also provides the Court with the opportunity to qualitatively increase national standards ${ }^{104}$ relating to the fair administration of justice.

EU:C:2015:307 at para 24; Opinion of Advocate General Bot in Case C-93/12 ET Agrokonsulting EU:C:2013:432 at para 30.

101 Case C-437/13 Unitrading EU:C:2014:2318.

102 Case C-331/13 Nicula EU:C:2014:2285.

103 See judgment of the Court of Appeal (England and Wales) (Civil Division) in Benkharbouche $v$ Sudan and Janah v Libya, $\mathrm{n} 87$.

104 Although note that this may not always be the case. In Melloni, a higher standard of fundamental rights protection was provided by the Spanish Constitution as interpreted in the case law and was in conflict with the European 
Indeed, the jurisprudence on EU asylum procedural law is developing at some pace in this respect. ${ }^{105}$ Legitimacy and equality are important constitutional values to uphold when ruling against national standards and take on particular significance in the area of freedom, security and justice. Article 47 EUCFR adheres to the regulatory goals of clarity and predictability. Furthermore, the open-textured nature of Article 47 enables the Court to be flexible and responsive in how it is interpreted and applied. ${ }^{106}$

Nevertheless, the diverse patterns that are emerging in the Court's case law could prove detrimental to the effectiveness of this area of EU law and the private model of enforcement. The improved visibility of the fundamental rights in the Charter has given rise to a huge proliferation of cases in which Article 47 is being invoked by litigants, sometimes in a spurious manner, in all areas of EU law and policy. The delegation of cases to the different Chambers of the Court is resulting in a multiplicity of different approaches being adopted. Indeed, at times, it is difficult to find a common thread to the Court's approach. This lack of consistency in the Court's judgments is causing legal uncertainty and a lack of clarity and predictability in the law. This in turn may undermine the effectiveness of the EU's reliance on private litigation before national courts to ensure compliance with EU law. This suggests that there are tensions being played out on a number of different planes. A number of observations can be made. First, as Chalmers correctly predicted, and as noted by Advocate General Bot in Melloni, ${ }^{107}$ there are tensions arising from the adoption of different lenses to interpret fundamental rights. In some cases such as Alassini, the Court is adopting a formalistic, pluralist approach in which it determines the standard of fundamental rights to be protected in reference not only to the Charter, but sources external to it such as the Explanations, international treaties such as the ECHR and national constitutional provisions. It recognizes and respects a range of sources of fundamental rights and is sensitive to the interplay between them. In other cases such as Liivimaa Lihaveis $M T \ddot{U}$, the Court is adopting a bolder, more 'Unionist' approach which accords to a particular vision of the EU

\footnotetext{
Arrest Warrant. The Court held that national standards of fundamental rights protection could only apply in accordance with Article 53 of the Charter if the level of protection provided in the Charter and the primacy, unity and effectiveness of EU law would not be comprised. In this case, EU law should prevail: Case C-399/11 Melloni EU:C:2013:107 at para 60.

105 See, for example, Marcelle Reneman, EU Asylum Procedures and the Right to an Effective Remedy (Hart Publishing, 2014).

106 Chalmers et al, n 95 at p 254.

107 Ibid p 261.
} 
legal order and making assessments which relate to the social, historical and cultural context of the legal order in question. ${ }^{108}$

Whilst an approach which reflects a singular EU view of remedies under the umbrella of Article 47 EUCFR may be more coherent, it is argued that there is merit in maintaining a pluralistic approach to remedies since the various sources of law differ in scope and have a range of functions. Article 47 will apply where the Member State is 'implementing EU law' only and is subject to the limitations and exceptions set out in Articles 52-54 EUCFR. Further, not all private litigation raises issues of fundamental rights. There are other procedural and remedial provisions which are a matter of policy choices and these may have evolved over many years and reflect cultural, political and budgetary choices. They may not infringe fundamental rights, but may affect the assertion of an EU right effectively and need to be challenged. And so, such sources need to be kept separate and autonomous as they may not always apply in a given scenario. There may also be mixed cases like Unitrading where the Court is unwilling to develop EU standards through its case law and prefers to leave such matters to the national legal orders.

It may take some time before the familiar tussles between the interests of the Member States seeking to preserve the integrity of their national legal order (subject to the minimum standards imposed by the principles of effectiveness and equivalence) and those seeking to rely on higher standards of judicial protection provided by EU law when asserting EU law rights now bolstered by the Charter have been teased out. These tensions previously existed in the case law. We are in an evolutionary period which will take time to settle down. The effectiveness of this arm of the EU's system of private enforcement may depend on the level of intrusion into their national legal orders that the Member States and their national courts deem legitimate and are prepared to accept.

\section{THE EFFECTIVENESS OF THE INSTITUTIONAL DESIGN OF THE PRIVATE ENFORCEMENT SYSTEM}

A full analysis of the EU's system of private enforcement can only be complete by moving beyond an analysis of the legal doctrines and viewing its institutional and operational features through the lens of our regulatory goals and constitutional values. First, we consider the impact of relying on

108 Advocate General Bot, n 93 at para 109. 
the case law as the key instrument in the building of the legal framework of this regulatory scheme. Second, we examine the effectiveness of the process by which the case law evolves in the EU context, namely through the preliminary ruling procedure.

\subsection{The Effectiveness of a Judge-Made System of Law}

For the most part, the laws governing the EU's private enforcement system continue to be developed and refined by the CJEU in a piecemeal manner. This poses a considerable challenge to achieving legal certainty and stability as well as clarity and predictability. There are certain characteristics of CJEU judgments which can exacerbate this tendency. First, the Court is prone to delivering opaque and ambiguous judgments. A lack of clarity in a judgment or in the meaning of EU law can give rise to further requests for preliminary rulings and the cycle of confusion and complexity continues. Indeed, as we are seeing post-Lisbon, it can take some time before the law on a particular issue is clearly established. ${ }^{109}$ As the workload of the Court increases, the delegation of cases to the different Chambers can result in divergent approaches emerging. These uncertainties can also stem from the collegiate nature of the judgments which reflect the majority view of the relevant Chamber of the Court. ${ }^{110}$ There are no dissenting judgments to shed light on any alternative interpretations that were considered. The judgment will be translated from the working language of the Court, which is French, into the other 24 official languages of the EU. Accuracy in translation can be an issue as different terms may have different meanings in the Member States. This too can lead to different interpretations and applications of the law emerging in the different Member States.

\section{Is there a case for legislation?}

A logical question would be to ask whether secondary legislation would improve the effectiveness of the legal framework from both regulatory and

109 For example, in Case C-453/99 Courage v Crehan [2001] ECR I-6297, the Court failed to clearly confirm whether or not it had created a right in EU law allowing individuals to sue other individuals for damages arising from losses sustained for breach of the EU competition rules and its scope. This gave rise to different applications of the judgments in the Member States. See further Assimakis Komninos, 'New Prospects for Private Enforcement of EC Competition Law: Courage v. Crehan and the Community Right to Damages' (2002) 39 Common Market Law Review 447.

110 See Lord Bingham's Foreword in Anthony Arnull, Piet Eeckhout and Takis Tridimas (eds), Continuity and Change in EU Law: Essays in Honour of Sir Francis Jacobs (OUP, 2008) at p vi. 
constitutional perspectives? Would it improve the individual's awareness of their rights by stating clearly whether or not a measure grants a directly effective right? Would an action be more swiftly resolved if secondary legislation clearly indicated the procedural rules and remedies which should apply? In theory, secondary legislation would allow greater compliance with the regulatory goals and constitutional values. However, introducing legislation is not a quick fix solution. Given the nature of EU law-making, the enactment of legislation raises complex legal and political questions.

In the context of private enforcement, the most fundamental issue is meeting the constitutional value of legality which relates to the need for legal competence. The principle of conferral requires a legal basis in the Treaty framework before the Commission can initiate legislation. The original European Economic Community (EEC) Treaty contained no specific legal base for introducing general legislation on procedural rules or remedies. ${ }^{111}$ Calls by the Commission, ${ }^{112}$ the Court ${ }^{113}$ and academics ${ }^{114}$ have not, in the past, led to this deficit being remedied on a general scale. ${ }^{115}$ The focus of the legislator has been on rule-setting rather than rule-enforcement. ${ }^{116}$ This does not mean in any way that no EU legislation exists which contains provisions relating to remedies or procedural rules. Yet, the overall pattern for many years has been one of sector specific measures. Whilst some policy areas have a high degree of harmonization, ${ }^{117}$ the most common approach has been to adopt measures which are fairly small scale in nature. ${ }^{118}$ It is argued that this traditional pattern is starting to shift, particularly where the EU has been given explicit competence to establish an Area of Freedom, Security and

111 For discussion of the creation of a new legal base, see Ch 10 in this volume.

112 Contribution by the Commission to the Intergovernmental Conference (1991) (Document drawn up on the basis of COM (90) 600 and SEC (91) 500) published in 'Intergovernmental Conferences: Contributions by the Commission' (1991) EC Bulletin, Supplement 2/91, pp 151-4.

113 Discussed above at $\mathrm{n} 54$.

114 Marcel Storme (ed), Report on the 'Approximation of Judiciary Law in the European Union' (Dordrecht: Martinus Nijhoff, 1994).

115 Chris Himsworth, 'Things Fall Apart: The Harmonisation of Community Judicial Procedural Protection Revisited’ (1997) 22 E.L.Rev. 291, Dougan, n 5 at pp 97-9.

116 Stephen Weatherill, 'Addressing Problems of International Implementation in EC Law' in Claire Kilpatrick, Tonia Novitz and Paul Skidmore, n 59 at 91.

117 The most harmonized field is that of public procurement.

118 Some measures represent a codification of the Court's case law on remedies: Article 11 of Council Directive 2000/78/EC of 27 November 2000 establishing a general framework for equal treatment in employment and occupation [2000] OJ L303/16 is the codification of the Court's judgment in Coote, n 62. 
Justice $^{119}$ or where the Commission sees private enforcement as a key part of its regulatory enforcement strategy, for example, EU anti-trust law. ${ }^{120}$ Once competence has been established, the Commission also has to comply with the principle of subsidiarity and proportionality. ${ }^{121}$ There is a strong argument for the governance of procedural rules and remedies to remain at national level on grounds of subsidiarity. There has to be a clear-cut case for it to be more effective to legislate at EU level. Moreover, such initiatives are now subject to the scrutiny of national parliaments. With regard to proportionality, the Commission will need to decide which instrument to adopt. Whilst regulations are best suited to achieving uniformity and arguably effectiveness, there are often arguments that directives are a more proportionate response to the objective to be achieved. Once these legislative and political hurdles have been overcome, it should not be forgotten that any legislation will have to be implemented by the Member States, applied by the national authorities and, in the event of a dispute, interpreted and applied by the national courts. All open up the possibility for the effectiveness to be undermined. ${ }^{122}$

\subsection{The Effectiveness of the Preliminary Ruling Procedure}

The way in which the Court and the preliminary ruling procedure function under Article 267 TFEU can undermine the development of the legal framework for private enforcement law in a manner which conflicts with the need for legal certainty and stability, and clarity and predictability. The process is dependent on the Court receiving an appropriate case in which it can extend or refine its regulatory scheme. Referral rates from the Member States can differ. The attitude of the national judges can be a significant factor. It is known that the length of proceedings can deter judges from referring in some Member States, and their propensity to refer may also depend on their knowledge and acceptance of EU law. Sanctions for failing to refer in accordance with

\footnotetext{
119 See Ch 10 in this volume.

120 See Ch 9 in this volume.

121 Article 5 TEU.

122 Consider the difficulties facing passengers seeking to enforce their right to compensation under Regulation (EC) No 261/2004 of the European Parliament and of the Council of 11 February 2004 establishing common rules on compensation and assistance to passengers in the event of denied boarding and of cancellation or long delay of flights, and repealing Regulation (EEC) No 295/91 [2004] OJ L46/1.
} 
Article 267 TFEU exist in the national law in some Member States, but not in all. At EU level, the sanction is arguably underdeveloped and lacks bite. In Köbler ${ }^{123}$ and Traghetti, ${ }^{124}$ the CJEU failed to rule that on the facts, a failure to refer by a national court of last resort under Article 267 (3) TFEU in these cases amounted to a sufficiently serious breach giving rise to state liability. ${ }^{125}$

There are also practical considerations. Not only does the 'right' question have to be referred to the Court, but the referral also needs to be allocated to the 'right' Advocate General and judges who will have to appreciate its significance for the development of EU law in the field of private enforcement. For that matter, if it is not clearly articulated by the national judge, an opportunity may indeed be missed to develop the legal framework further. Having said that, the Court may spot an opportunity and exploit it, reformulating the question referred as it did in the $D E B$ case. As we have seen in the post-Lisbon case law, it is clear that variations in interpretations occur, particularly on new areas of law pending a Grand Chamber judgment. This may depend on whether there is agreement between the judges as to the guidance to be given to a national court to resolve the matter before it. This may not simply depend on the EU judges, but on the amount of information the Court has been given by the national court on the facts of the case. It may be that the issue is deemed 'sensitive' and that the Court does not want to be seen to 'interfere' in certain areas of law and policy. Indeed, this has been a key issue for the Court in the area of private enforcement which has led to inconsistency in its judgments. Furthermore, despite the elaboration of principles at Union-wide level, their effective application often depends on the attitude of the national courts. In general, there has been widespread acceptance of the Court's judgments by the national courts, but at times, it can be less than satisfactory and can lead to diversity in the level of protection available. ${ }^{126}$ The EU's current judicial architecture presents real challenges to developing a body of law which is visible, clear and coherent, and as a consequence, there is a lack of legal certainty and predictability for all parties involved in the proceedings.

123 Case C-224/01 Köbler [2003] ECR I-10239.

124 Case C-173/03 Traghetti [2006] ECR I-5177.

125 Sara Drake, 'State Liability for Judicial Error: All Bark and No Bite? The Consequences of National Courts' Failure to Refer' in Adam Cygan and Lorenzo Spadacini (eds), Constitutional Implications of the Traghetti Judgment: Italian and European Perspectives (Bibliofabbrica, 2010) pp 49-79.

126 See Komninos, n 109. 


\section{CONCLUDING REMARKS}

This chapter adopts an innovative analytical approach drawn from regulatory scholarship to evaluate the effectiveness of the EU's private enforcement model. It brings a fresh perspective to the debate on effective enforcement by making a broader, more contextual assessment of the EU acquis including post-Lisbon developments as well as the judicial architecture and processes. Starting from the premise that the EU's private enforcement system is a regulatory scheme seeking to achieve the collective regulatory goal of effective compliance of EU law, a normative framework of carefully selected regulatory goals and constitutional values was constructed. This theoretical framework was then mapped first against the key legal doctrines governing rights, remedies and procedural rules which underpin the private enforcement regime before moving on to assess two constitutional innovations set out in the Treaty of Lisbon. Finally, for a more complete and holistic assessment, the method of constructing a regulatory scheme through case law and the preliminary ruling procedure was also assessed. This systematic approach enables us to identify the strengths and weaknesses of each aspect of the private enforcement system and enriches our understanding of the Court's policy in pursuit of the overall regulatory goal of effective compliance with EU law.

The analysis reveals that there is a persistent tension in the legal doctrines upon which the EU's system of private enforcement is based. The Court's policy sways between prioritizing the constitutional values of legality and legitimacy on the one hand and those of effective judicial protection and equality on the other. It is also evident from the case law that there have been shifts in policy which have led to an expansion or limitation of the legal doctrine in response to the reactions of Member States and their national courts. When asserting EU rights, the Court's persistent refusal to recognize the horizontal direct effect of directives demonstrates that it has prioritized legality, legitimacy and legal certainty over equality and the effective judicial protection of individuals' EU rights. It has sought to compensate for the inequality this creates in a responsive manner by developing alternative methods for individuals to enforce their rights such as the doctrine of indirect effect. Yet, this creates new tensions with the legality and legitimacy of its rulings. From a regulatory perspective, whilst the Court's actions have led to a system which is responsive and flexible, it lacks clarity and predictability and is arguably overly complex.

When determining the applicable procedural and remedial rules, the Court's two approaches both satisfy our normative framework to a large 
degree. The application of the principles of effectiveness and equivalence are considered to have a high degree of legitimacy, but can cause inequality, uncertainty and a lack of predictability. The more interventionist approach which has resulted in the introduction of the doctrine of state liability achieves high levels of effective judicial protection for individual actors, and slightly more equality, yet its legitimacy has been rigorously questioned. What is certain is that the current approach of 'selective deference' seems to be the least appropriate in order to achieve effectiveness creating higher levels of uncertainty.

The Treaty of Lisbon was a missed opportunity to address the deficiencies in the EU's private enforcement system and to provide a clear legal and legitimate Treaty base for the Court's jurisprudence. What is clear is that post-Lisbon, we have moved into a new phase in the development of the Court's jurisprudence on private enforcement and specifically on remedies. The Treaty of Lisbon has given the Court the constitutional tools required to align to a greater extent the regulatory goals and constitutional values upon which this regulatory scheme is based, and improve its effectiveness in the field of remedies. The Court has seized the opportunity presented by Article 47 of the EUCFR to increase the legality and legitimacy of its previous case law and, for the most part, to insert higher standards of judicial protection into the legal orders through the national courts. Yet, the lack of clarity in relation to definitions of key concepts, their scope and interrelationship with existing case law are proving to complicate matters further. There is serious potential for the complexity to increase and a danger that the system becomes unworkable. In contrast, the Court has yet to embrace the full potential of Article 19(1) TEU, second subparagraph, to strengthen not only the legality and legitimacy of its existing remedies case law, but also to qualitatively increase the standards of remedies in a non-fundamental rights context. This would promote an alignment of the regulatory goals and constitutional values and improve the effectiveness of important aspects of the private enforcement system.

The chapter also considers how the institutional design of the model of private enforcement can impinge on its effectiveness. It is clear that the construction of a private enforcement system through case law can present challenges to the constitutional values of legal certainty and stability and the corresponding regulatory goals of clarity and predictability. Whilst it is acknowledged that these pressures are not confined to EU law, they are exacerbated in the EU context by the nature of the Court's judgments and its heavy workload. The enactment of EU secondary legislation may appear to be the solution, but this possibility raises further challenges, particularly in relation to legality and legitimacy. An analysis of the 
functioning of preliminary ruling procedure reveals that the Court has put in place legal principles to enhance legal certainty and stability as well clarity and predictability. Yet, the effectiveness of the procedure is also contingent on the broader context in which it operates including sociolegal factors and judicial politics, undoubtedly fertile ground for further research. 